\title{
Sex Hormone Regulation of Proteins Modulating Mitochondrial Metabolism, Dynamics and Inter-Organellar Cross Talk in Cardiovascular Disease
}

\section{OPEN ACCESS}

Edited by:

Gaetano Santulli,

Columbia University, United States

Reviewed by:

Sara Baldelli,

Università telematica San Raffaele,

Renée Ventura-Clapier,

Centre National de la Recherche

Scientifique (CNRS), France

*Correspondence:

Samantha Giordano-Mooga

sgiordan@uab.edu

Specialty section

This article was submitted to

Cellular Biochemistry,

a section of the journal

Frontiers in Cell and Developmental

Biology

Received: 26 September 2020

Accepted: 30 November 2020

Published: 11 February 2021

Citation:

Lynch S, Boyett JE, Smith MR and Giordano-Mooga S (2021) Sex Hormone Regulation of Proteins

Modulating Mitochondrial

Metabolism, Dynamics and Inter-Organellar Cross Talk

in Cardiovascular Disease.

Front. Cell Dev. Biol. 8:610516. doi: 10.3389/fcell.2020.610516

\author{
Shannon Lynch ${ }^{1}$, James E. Boyett ${ }^{2}$, M. Ryan Smith ${ }^{3}$ and Samantha Giordano-Mooga ${ }^{2 \star}$ \\ ${ }^{1}$ Biomedical Sciences Program, Graduate School, University of Alabama at Birmingham, Birmingham, AL, United States, \\ ${ }^{2}$ Biomedical Sciences Program, Department of Clinical and Diagnostic Science, University of Alabama at Birmingham, \\ Birmingham, AL, United States, ${ }^{3}$ Division of Pulmonary, Allergy and Critical Care Medicine, Emory University, Atlanta, GA, \\ United States
}

Cardiovascular disease (CVD) is the leading cause of death in the U.S. and worldwide. Sex-related disparities have been identified in the presentation and incidence rate of CVD. Mitochondrial dysfunction plays a role in both the etiology and pathology of CVD. Recent work has suggested that the sex hormones play a role in regulating mitochondrial dynamics, metabolism, and cross talk with other organelles. Specifically, the female sex hormone, estrogen, has both a direct and an indirect role in regulating mitochondrial biogenesis via PGC-1 $\alpha$, dynamics through Opa1, Mfn1, Mfn2, and Drp1, as well as metabolism and redox signaling through the antioxidant response element. Furthermore, data suggests that testosterone is cardioprotective in males and may regulate mitochondrial biogenesis through PGC-1 $\alpha$ and dynamics via Mfn1 and Drp1. These cell-signaling hubs are essential in maintaining mitochondrial integrity and cell viability, ultimately impacting CVD survival. PGC-1 $\alpha$ also plays a crucial role in inter-organellar cross talk between the mitochondria and other organelles such as the peroxisome. This inter-organellar signaling is an avenue for ameliorating rampant ROS produced by dysregulated mitochondria and for regulating intrinsic apoptosis by modulating intracellular $\mathrm{Ca}^{2+}$ levels through interactions with the endoplasmic reticulum. There is a need for future research on the regulatory role of the sex hormones, particularly testosterone, and their cardioprotective effects. This review hopes to highlight the regulatory role of sex hormones on mitochondrial signaling and their function in the underlying disparities between men and women in CVD.

Keywords: sexual dimorphism, cardiovascular disease, estrogen, testosterone, mitochondria

\section{CARDIOVASCULAR DISEASE AND SEX STEROID SIGNALING}

Cardiovascular disease (CVD) is modulated by mitochondrial dysfunction, calcium handling, aging, etc., which are reviewed in detail in the corresponding reviews (Khoury et al., 1992; Sandstede et al., 2000; Berridge, 2003; Lou et al., 2012; Keller and Howlett, 2016; Ventura-Clapier et al., 2017; Virani et al., 2020). Sex disparities in the cardiovascular system including heart size, body 
size, adipose deposition, etc. have been linked to variations in CVD risk and rates. In this review, we will focus on sex hormone driven differences in CVD. In general, women express higher levels of estrogen and estrogen receptors (ERs) than men, while men express higher levels of testosterone and androgen receptors (ARs) than women; as both sexes age, there is a decrease in the predominant sex hormone. While the primary sex hormone decreases, there is a concurrent increase in estrogen in men and an increased ratio of testosterone to estrogen in women (Araujo and Wittert, 2011; Bowling et al., 2014; Zhao et al., 2018).

Currently, there are conflicting results on the role of testosterone in CVD, but it is documented that the decrease in testosterone in men with age and the higher ratio of testosterone to estrogen in post-menopausal women may be linked to increased CVD incidence (Freeman et al., 2010; Elagizi et al., 2018). Human studies have shown confounding results regarding the cardioprotective effects of menopausal hormone therapy to increase estrogen levels in women during the post-menopausal period (Stampfer et al., 1991; Rossouw et al., 2002; Hodis and Mack, 2014). The stark decrease in estrogen levels in the post-menopausal period have also been linked to obesity and metabolic syndrome incidence (Araujo and Wittert, 2011; Ziaei and Mohseni, 2013; Bowling et al., 2014; Moore et al., 2017; Zhao et al., 2018; Terrazas et al., 2019). The sex hormones also regulate differences in metabolism, specifically in regards to fat accumulation and body shape between men and women, which are known modulators of CVD risk (Bjorntorp, 1997; Fui et al., 2014; Mercado et al., 2015; Van Pelt et al., 2015; Leeners et al., 2017; Terrazas et al., 2019). The metabolic differences associated with changes in hormone status-which are influenced by a plethora of factors including sex chromosomes, gene expression and regulation, and epigenetics-are key to understanding CVD disparities between men and women (Ventura-Clapier et al., 2019). This review will focus on sex hormone signaling and its potential cardioprotective effects, discuss controversial findings regarding sex hormone signaling, and highlight the need for further research to create efficacious and sex-specific CVD treatments.

To elucidate the roles of estrogen and testosterone in CVD, it is essential to understand the roles of their associated receptors, including estrogen receptor alpha $(\mathrm{ER} \alpha)$, estrogen receptor beta $(\mathrm{ER} \beta), \mathrm{G}$ protein coupled estrogen receptor (GPER/GCPR30), and ARs. The regulation of estrogen and androgen receptor expression is challenging to study, as they are sex-, age-, cell type-, and organelle-specific (Lizotte et al., 2009; Dart et al., 2013; Bowling et al., 2014; Hutson et al., 2019). At the cellular level, it has been shown that varying cell types express different levels of sex hormone receptors, highlighting that each organ system may have differential sexual dimorphic regulation (Erlandsson et al., 2001; Deroo and Korach, 2006; Levin, 2009; Dart et al., 2013; Mahmoodzadeh and Dworatzek, 2019; Ventura-Clapier et al., 2019). Within the cell, sex hormone receptors can be found in a variety of locations including the cell membrane, nucleus, mitochondria, and endoplasmic reticulum, although, again, these locations vary depending upon the cell type (Levin, 2009; Lizotte et al., 2009; Luo and Kim, 2016; Pedernera et al., 2017). In cardiomyocytes, the hormone receptors are expressed at different locations on various organelles; for example, both $\mathrm{ER} \alpha$ and $\operatorname{ER} \beta$ have been found to be localized to the mitochondria, while GPER has been localized to both the cell membrane and the endoplasmic reticulum (Lizotte et al., 2009; Luo and Kim, 2016; Zimmerman et al., 2016; Pedernera et al., 2017; Gourdy et al., 2018; Ventura-Clapier et al., 2019). While receptor expression within the cardiovascular system is known, further studies understanding how the ERs and ARs change based on age and hormone status is needed.

The mitochondrion plays an integral role in the production of the steroid hormones, as it is the site wherein the first step of sex hormone synthesis occurs (Miller, 2013). These same sex hormones are implicated in regulating mitochondrial dynamics and function. Cholesterol is the building block for the steroid hormones, specifically the C27-steroid cholesterol, which enters the mitochondria through the steroidogenic acute regulatory protein where the cytochrome P450 enzyme, CYP11A1, produces pregnenolone; pregnenolone can subsequently be transported back into the cytosol and converted, through a series of enzymatic steps, into either estrogen (estradiol) or testosterone ( $\mathrm{Hu}$ et al., 2010; Miller and Bose, 2011; Samavat and Kurzer, 2015). The enzyme aromatase converts testosterone into estradiol, and recent studies have found elevated aromatase correlates with metabolic dysfunction in women (Araujo and Wittert, 2011; Iyengar et al., 2017). It has also been shown that adipose tissue is the primary producer of estrogen in post-menopausal women, adding to the complexity of estrogen signaling (Cleland et al., 1985; Chen and Madak-Erdogan, 2018). The differences in serum estrogen and testosterone levels can greatly influence cellular processes and adipose deposition, which can modulate CVD risk.

Testosterone and dihydrotestosterone activate the nuclear AR, which regulates transcription of genes located near androgen response elements or via a DNA binding independent pathway to activate ERK, Akt, and MAPK pathways (Benten et al., 1999b; Davey and Grossmann, 2016). Plasma membrane associated ARs play an important role in calcium $\left(\mathrm{Ca}^{2+}\right)$ signaling, in addition to influencing endoplasmic reticulum signaling and apoptosis (Benten et al., 1999a,b; Segawa et al., 2002; Davey and Grossmann, 2016; Azhary et al., 2018). AR and androgen hormones are also essential for the development and normal physiology of the cardiovascular system (Ikeda et al., 2005). In comparison, the classical pathway of $\mathrm{ER} \alpha$ activation involves its association with heat shock proteins within the cytosol; once estrogen binds $\mathrm{ER} \alpha$ and/or $\mathrm{ER} \beta$, they can dimerize and translocate to the nucleus to activate transcription via the estrogen response element (Levin, 2009). ER $\alpha$ has also been shown to induce signaling cascades -including Akt, PKA and ERK1/2, and eNOS - through a membrane-initiated sequence whereby a post-translationally modified pool of $\mathrm{ER} \alpha$ is localized near the plasma membrane due to an interaction with caveolin 1 (Levin, 2009; Yasar et al., 2017). After estrogen binds the receptor, it induces additional signaling pathways. ER $\alpha$ and $\operatorname{ER} \beta$ are found on the plasma membrane, as both homo- and heterodimers, and expression is differential based on cell type, as previously mentioned (Li L. et al., 2003; Levin, 2009; Bowling et al., 2014). ER $\beta$ has been shown to localize to the mitochondria in cardiomyocytes of both humans and rodents, and has been 
proposed to play a role in mitochondrial integrity (Yang et al., 2004). GPER, a membrane-bound estrogen receptor, induces cAMP, IP3, $\mathrm{Ca}^{2+}$, and the MAPK/ERK pathways (Aronica et al., 1994; Improta-Brears et al., 1999; Filardo et al., 2000). Unlike $\mathrm{ER} \alpha$ and $\mathrm{ER} \beta$ expression, which are strictly regulated by estrogen levels and decrease in the post-menopausal period, GPER levels appear to be unaffected by circulating estrogen levels induced by menopause, but may fluctuate with estrous cycle (Cheng et al., 2014; Zimmerman et al., 2016). Data also suggests that GPER activation is protective after a vascular injury in $\operatorname{ER} \alpha$ and $\operatorname{ER} \beta$ $\mathrm{KO}$ mice, and can regulate mitochondrial function and biogenesis in ovariectomized mice (Bowling et al., 2014; Sbert-Roig et al., 2016; Mahmoodzadeh and Dworatzek, 2019). Therefore, more research is needed to determine the expression and role of GPER in preventing CVD injury.

\section{CELLULAR METABOLISM}

Mitochondria play a crucial role in many molecular pathways and cellular bioenergetics. Mitochondria comprise about $35 \%$ of the entire cell volume in cardiomyocytes, making their function even more crucial to proper cardiovascular function (Dedkova and Blatter, 2012; Consolini et al., 2017). The mitochondrion contains its own small genome, encoding 37 mitochondrial proteins which are translated in the mitochondria, while the remaining proteins and RNAs are encoded by the nuclear genome (Lee and Han, 2017). Since the majority of mitochondrial proteins arise from nuclear transcription, cross talk between the mitochondria and the nucleus is imperative for effective metabolism and function. Mitochondrial proteins and their precursors are transported from cytosolic ribosomes and the endoplasmic reticulum into the mitochondria and then integrated with mitochondriallyderived proteins via sorting, assembly, and importing machinery (Pfanner and Meijer, 1997; Ellenrieder et al., 2015, 2017; Doan et al., 2020). This, in conjunction with the formation of phospholipid precursors by the endoplasmic reticulum for the mitochondria, such as cardiolipin, shows the importance of cross communication for proper mitochondrial function, as well as modulation by hormones (Ellenrieder et al., 2017; Pozdniakova et al., 2018; Acaz-Fonseca et al., 2020).

Mitochondria utilize a variety of energy sources including glucose, fatty acids, and amino acids to produce reducing equivalents for mitochondrial respiration and ATP production, which is essential in cardiac tissue. Developing cardiomyocytes prefer glucose as their energy source, whereas adult cardiomyocytes prefer fatty acids; recent studies suggest that alteration of energy sources in cardiomyocyte metabolism can contribute to CVD progression (Piquereau et al., 2010, 2012; Krzywanski et al., 2011; Martin et al., 2014; Siasos et al., 2018). Mitochondrial metabolism produces reactive oxygen species (ROS), which are increased in mitochondrial dysfunction and prevalent in CVD (Wang and Zou, 2018). To reduce ROS, antioxidant proteins, including superoxide dismutase 1 (SOD1), SOD2, and glutathione peroxidase $(\mathrm{GPx})$ can be upregulated (Table 1). In the heart, estrogen and testosterone have been shown to increase these antioxidant enzymes, and may act in a cardioprotective manner (Barp et al., 2002; Strehlow et al., 2003; Zhang et al., 2011; Lee et al., 2012; Liu H. et al., 2014; Liu Z. et al., 2014; Redmann et al., 2014; Pozdniakova et al., 2018; Mahmoodzadeh and Dworatzek, 2019; Ventura-Clapier et al., 2019; Asmis and Giordano-Mooga, 2020; Casin and Kohr, 2020). In the vasculature, GPER has been shown to modulate ROS through downregulation of oxidative stress proteins such as NADPH oxidase 4 (NOX4), Prostaglandin-endoperoxide synthase 2 (PTGS2), and GPx1 in addition to upregulating antioxidant proteins such as SIRT3 and GSTK1 (Wang H. et al., 2018; Ogola et al., 2019). Additionally, it has been shown that GPER downregulates an essential autophagy protein light chain 3-LC3I/LC3II-via upregulation of PTEN-induced putative kinase 1 (PINK1), and a concurrent decrease in mitochondrial parkin localization indicating a decrease in mitophagy (Feng et al., 2017). GPER activation, through mitochondrial and lysosomal cross talk mechanisms, is an important mitigator of ROS in CVD (Lee et al., 2012; Feng et al., 2017). These same antioxidant proteins have been associated with peroxisomal function and are key players in the peroxisome's regulation of intracellular ROS levels (Schrader and Fahimi, 2006; Wang Q. et al., 2015). Because ROS regulation is critical in metabolic homeostasis and mitochondrial dynamics, perturbation of these processes often leads to increased risk of pathological outcomes, such as CVD (Krzywanski et al., 2011; Siasos et al., 2018). Hence, understanding how mitochondrial dynamics and cross talk are impacted by ROS and modulated by sex hormones is critical in elucidating the mechanisms underlying CVD.

\section{MITOCHONDRIAL BIOGENESIS AND DYNAMICS}

Under normal conditions, mitochondrial turnover in the adult heart occurs every 2 weeks (Dorn et al., 2015). Mitochondrial dynamics is the process of mitochondrial growth and division designed to maintain homeostasis by utilizing the fission, fusion, mitophagy, and recycling processes during growth and development as well as under environmental stressors such as ischemia, hypoxia, or oxidative stress (Dorn et al., 2015; Dorn, 2016). Recent studies have shown that regulating mitochondrial homeostasis is crucial in mitigating CVD disruption of these processes which has been previously to worse pathological outcomes or increased death (Jornayvaz and Shulman, 2010; Sun et al., 2013; Redmann et al., 2014). Peroxisome proliferatoractivated receptor gamma coactivator 1-alpha $(\mathrm{PGC}-1 \alpha)$ is a transcriptional coactivator protein crucial for maintaining homeostasis of this organelle by targeting genes involved in electron transport chain (ETC) and apoptotic signaling (Liang and Ward, 2006; Lai et al., 2008; Wang F. et al., 2015). AMPactivated protein kinase (AMPK) is an upstream regulator of PGC- $1 \alpha$ involved in energy homeostasis and mitochondrial biogenesis and has been shown to be regulated through the sex hormones (Jornayvaz and Shulman, 2010; Varanita et al., 2015; Wang F. et al., 2015; Park et al., 2017; Hevener et al., 2020). In cardiomyocytes, activated estrogen receptors found on the cell membrane can upregulate PGC- $1 \alpha$ activity, thereby 
TABLE 1 | Impact of sex hormones on cardiac cell protein expression.

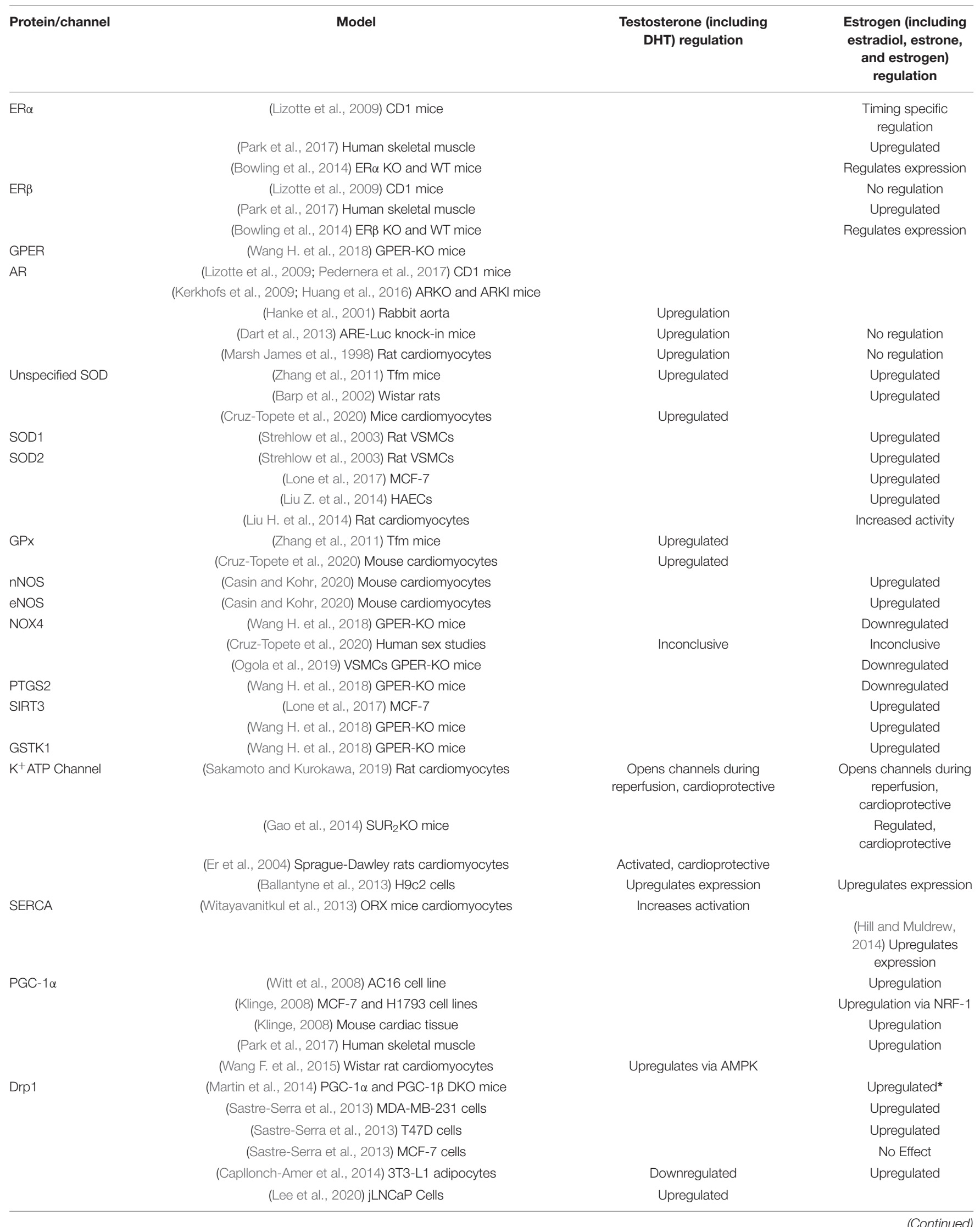


TABLE 1 | Continued

\begin{tabular}{|c|c|c|c|}
\hline Protein/channel & Model & $\begin{array}{l}\text { Testosterone (including } \\
\text { DHT) regulation }\end{array}$ & $\begin{array}{l}\text { Estrogen (including } \\
\text { estradiol, estrone, } \\
\text { and estrogen) } \\
\text { regulation }\end{array}$ \\
\hline \multirow[t]{7}{*}{ Mfn1 } & (Martin et al., 2014) PGC-1 $\alpha$ and PGC-1 $\beta$ DKO mice & & Upregulated* \\
\hline & (Papanicolaou et al., 2012) Mouse cardiomyocytes & & Upregulated* \\
\hline & (Sastre-Serra et al., 2013) MDA-MB-231 cells & & Upregulated \\
\hline & (Sastre-Serra et al., 2013) T47D cells & & Upregulated \\
\hline & (Sastre-Serra et al., 2013) MCF-7 cells & & Upregulated \\
\hline & (Capllonch-Amer et al., 2014)3T3-L1 adipocytes & Upregulated & No Effect \\
\hline & (Lee et al., 2020) LNCaP cells & No Effect & \\
\hline \multirow[t]{6}{*}{ Mfn2 } & (Martin et al., 2014)PGC- $1 \alpha$ and PGC-1 $\beta$ DKO mice & & Upregulated* \\
\hline & (Papanicolaou et al., 2012) Mouse cardiomyocytes & & Upregulated* \\
\hline & (Sastre-Serra et al., 2013) MDA-MB-231 cells & & Upregulated \\
\hline & (Sastre-Serra et al., 2013) T47D cells & & Upregulated \\
\hline & (Sastre-Serra et al., 2013) MCF-7 cells & & Upregulated \\
\hline & (Lee et al., 2020) LNCaP cells & No Effect & \\
\hline \multirow[t]{6}{*}{ Opa1 } & (Martin et al., 2014) PGC-1 $\alpha$ and PGC-1 $\beta$ DKO mice & & Upregulated* \\
\hline & (Sastre-Serra et al., 2013) MDA-MB-231 cells & & Upregulated \\
\hline & (Sastre-Serra et al., 2013) T47D cells & & Upregulated \\
\hline & (Sastre-Serra et al., 2013) MCF-7 cells & & Upregulated \\
\hline & (Capllonch-Amer et al., 2014) 3T3-L1 adipocytes & No Effect & Upregulated \\
\hline & (Lee et al., 2020) LNCaP cells & No Effect & \\
\hline \multirow[t]{6}{*}{ Fis1 } & (Martin et al., 2014) PGC-1 $\alpha$ and PGC-1 $\beta$ DKO mice & & Upregulated* \\
\hline & (Sastre-Serra et al., 2013) MDA-MB-231 cells & & No effect \\
\hline & (Sastre-Serra et al., 2013) T47D cells & & No effect \\
\hline & (Sastre-Serra et al., 2013)MCF-7 cells & & Downregulated \\
\hline & (Capllonch-Amer et al., 2014) 3T3-L1 adipocytes & Downregulated & No effect \\
\hline & (Lee et al., 2020) LNCaP cells & No effect & \\
\hline PINK1 & (Feng et al., 2017) Sprague-Dawley rats & & Upregulated \\
\hline \multirow[t]{2}{*}{ LC3I/LC3II } & (Feng et al., 2017) Sprague-Dawley rats & & Downregulated \\
\hline & (Papanicolaou et al., 2012) Mouse cardiomyocytes & & Downregulated* \\
\hline
\end{tabular}

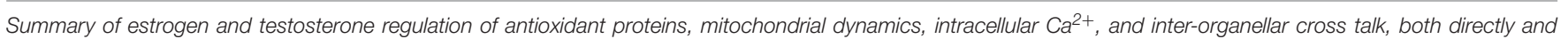
indirectly.

${ }^{*}$ Proteins indirectly regulated by the sex hormones via PGC-1 $\alpha$.

regulating ATP synthesis, substrate oxidation, and phosphate transfer (Klinge, 2008; Witt et al., 2008). PGC-1 $\alpha$ can also target genes that regulate metabolism in the heart, such as estrogenrelated receptor alpha $(E R R \alpha)$, which protects against stressors of CVD (Huss et al., 2004; Martin et al., 2014; Li H. et al., 2015). While estrogen does not directly bind to ERR $\alpha$, it activates genes regulated to mitochondrial biogenesis, and further studies are needed to understand the sexually dimorphic regulation (Horard and Vanacker, 2003). These data indicate a crucial signaling role for estrogen in the maintenance of mitochondria.

Estrogen has also been shown to activate peroxisome proliferator-activated receptor $\alpha$ (PPAR $\alpha)$, a partner of PGC$1 \alpha$, which functions to transcriptionally regulate fatty acid metabolism in the heart. Activation of PPAR $\alpha$ induces the expression of Pex genes leading to peroxisomal biogenesis, while simultaneously inducing the expression of mitochondrial fusion and fission proteins mitofusin 1 (Mfn1), mitofusin 2 (Mfn2), dynamin-related protein-1 (Drp1), and fission protein 1 (Fis1) (Table 1; Bagattin et al., 2010; Papanicolaou et al., 2012;
Schrader et al., 2012; Martin et al., 2014; Varanita et al., 2015). Increased number of peroxisomes in conjunction with sustained mitochondrial integrity increases $\beta$-oxidation of long chain fatty acids and fatty acid-induced cellular respiration. It has been further suggested that these tissues upregulate PGC-1 $\alpha$ in response to increased lipid intake, acting as a compensatory mechanism for high fat diets and metabolic dysregulation. This co-regulation of peroxisomal and mitochondrial biogenesis has been established in brown adipose tissue, liver and skeletal muscle (Huang et al., 2017, 2019; Hevener et al., 2020). Work has yet to be done showing the proliferation of peroxisomes in cardiac tissue, but findings in other tissues is highly suggestive of the need for future research in this area.

PPAR $\alpha$ KO mice have severely impaired cardiac function due to lipid accumulation and hypoglycemia which causes death in all males but only $25 \%$ of females; however, pretreatment of $\beta$-estradiol in males with ablated PPAR $\alpha$ survived, implicating estrogen signaling as a crucial mechanism for cardiac metabolism (Nöhammer et al., 2003). Estrogen plays a crucial role in 
cardiac lipid metabolism for both males and females in vivo (Djouadi et al., 1998). This data, again, highlights the importance of estrogen signaling in cardiac metabolism.

Many cardiovascular pathologies have notable alterations in mitochondrial network morphology. Mitochondrial fission is a process by which mitochondria alter their physical structure; symmetrical division for replication or asymmetrical division to remove damaged organelle components (Shirihai et al., 2015). Asymmetrical fission acts as quality control for damaged mitochondria resulting in fragmentation, which can be utilized for selective mitophagy (Ong et al., 2010; Shirihai et al., 2015). While both processes serve as protective mechanisms for cellular damage and apoptosis through the mitochondria, the mechanisms of activation via other cellular organelles are different. In mitochondrial fusion, the mitochondria fuse with other organelles to repair and regenerate, as opposed to mitochondrial fission, where DNA replication is upregulated in response to mitochondrial damage, inhibiting cytochrome c release and corresponding apoptosis (Chen et al., 2012; Varanita et al., 2015; Dorn, 2016; Hevener et al., 2020). Major proteins associated with fission and fusion include Drp1, Fis1, Mfn1 and Mfn2, and the optic atrophy-1 protein (Opa1). Drp1 is recruited to the outer mitochondrial matrix (OMM) and has been shown to interact with the endoplasmic reticulum, highlighting the importance of inter-organellar cross talk during mitochondrial fission events (Ishihara et al., 2009). Mfn1 and 2 are responsible for fusing OMMs and tethering the mitochondria to the SR for $\mathrm{Ca}^{2+}$ signaling, making mitofusin proteins indispensable to inter-molecular and interorganellar interactions (Chen et al., 2012). These proteins also have an important role in mitochondrial quality control by mediating fusion, guiding protein folding, and preventing ROSinduced mitophagy (Shirihai et al., 2015; Song et al., 2015). Opal mediates inner mitochondrial membrane fusion and maintains cristae structure, which ensures proper ETC function (Varanita et al., 2015). This increase in cristae integrity can reduce ROS and prevent cytochrome $c$ release, preventing and reducing mitochondrial dysfunction and apoptosis in highlymetabolic tissues, like the heart and brain (Ong et al., 2010; Varanita et al., 2015).

Abnormal fission and fusion leading to reduced cristae integrity and less functionally efficient morphology-overtly spherical or elongated-are known contributors to heart failure due to their effects on metabolism and apoptosis (Ong et al., 2010; Papanicolaou et al., 2012; Dorn, 2016). Mitochondrial fission opens the mitochondrial permeability transition pore (MPTP) which can result in cell necrosis or mitophagy if not properly managed, as seen in ischemic conditions (Parra et al., 2008; Shirihai et al., 2015; Song et al., 2015). Activation of GPER and ER $\alpha$ has been shown to preserve mitochondrial function and decrease mitophagy after ischemia reperfusion injury via MPTP signaling through MEK/ERK activation, thereby decreasing apoptosis (Feng et al., 2017; Mahmoodzadeh and Dworatzek, 2019). These data, again, suggest the estrogen has cardioprotective effects by preserving mitochondrial integrity and inhibiting apoptosis. Testosterone has also been shown to protect against myocardial infarction through the AMPK pathway, elevating PGC-1 $\alpha$ and preserving mitochondrial integrity leading to decreased cardiomyocyte apoptosis, as demonstrated by rodent models (Witt et al., 2008; Wang F. et al., 2015). The ability of both estrogen and testosterone to activate PGC-1 $\alpha$ in cardiac tissue has been extensively studied, and it is well-established that PGC- $1 \alpha$ regulates the transcription of Drp1, Fis1, Mfn1, Mfn2, Opa1, and other important mitochondrial dynamic proteins (Table 1; Witt et al., 2008; Papanicolaou et al., 2012; Martin et al., 2014; Wang F. et al., 2015; Park et al., 2017). This therefore implies a potentially shared pathway for cardioprotection by estrogen and testosterone, but direct evidence has remained elusive. Adding to the complexity, direct regulation of mitochondrial dynamics by the sex hormones has been well established in brain, breast cancer, prostate cancer, and adipocyte models but more research is needed to better characterize the direct effects of estrogen and testosterone in modulating signaling in cardiac tissue as well as inter-organellar cross talk between the mitochondria and other cellular organelles (Sastre-Serra et al., 2013; Capllonch-Amer et al., 2014; Lejri et al., 2018; Lee et al., 2020).

\section{SARCOPLASMIC RETICULUM AND MITOCHONDRIAL CROSS TALK}

The $\mathrm{K}_{\mathrm{ATP}}$ channel, found on both the mitochondria and the sarcoplasmic reticulum (SR), alters the electrochemical gradient through an influx of $\mathrm{K}^{+}$into each organelle (Ranki et al., 2002; Er et al., 2004; Ballantyne et al., 2013; Gao et al., 2014; Bayat et al., 2016; Sakamoto and Kurokawa, 2019). In the mitochondrion, this change in $\mathrm{K}^{+}$concentration causes an increase in $\mathrm{K}^{+} / \mathrm{H}^{+}$antiporter activity, inducing an efflux of $\mathrm{H}^{+}$ions from the mitochondrial intermembranous space. The resulting decreased membrane potential impairs organelle efficiency and reduces mitochondrial production of ATP. The activation of the $\mathrm{K}_{\mathrm{ATP}}$ channel by both estrogen and testosterone has been shown to be cardioprotective in models of ischemia reperfusion injury (Er et al., 2004; Ballantyne et al., 2013; Gao et al., 2014; Sakamoto and Kurokawa, 2019). Estrogen, but not testosterone, can also regulate the SR $\mathrm{K}_{\mathrm{ATP}}$ channel, which has also been shown to preserve cardiac function after ischemia reperfusion injury (Ranki et al., 2002). Evidence further suggests that testosterone may have a down-regulation effect on SR $\mathrm{K}_{\mathrm{ATP}}$ channels in exercise models, suggesting a potentially antithetical effect from estrogen (Bayat et al., 2016). GPER activation has also been indicated as a possible mitigator of cell death during reperfusion injury through modulation of mitochondrial integrity, further supporting estrogen's cardioprotective properties (Lee et al., 2012; Feng et al., 2017; Groban et al., 2019). Taken together, these data suggest potential mechanisms of cardioprotection via sex hormone regulation of $\mathrm{K}_{\mathrm{ATP}}$ channels on mitochondria and sarcoplasmic reticula.

Another important ion to consider in this interorganellar crosstalk is calcium $\left(\mathrm{Ca}^{2+}\right) \cdot \mathrm{Ca}^{2+}$ is a divalent ion, and an essential mineral vital for cellular signaling, which has been a critical area of study for several decades (Berridge, 2003; Brookes 
et al., 2004; Clapham, 2007). Calcium signaling has also been extensively studied in the mitochondrion and plays important roles in the regulation of many enzymes in the Krebs cycle, electron transport complexes such as ATP synthase, as well as many other enzymes (Das and Harris, 1990; McCormack et al., 1990; Consolini et al., 2017). In cardiomyocytes, an essential mechanism of cardiac function is the maintenance of high levels of ATP in order to properly activate SERCA-a $\mathrm{Ca}^{2+}$ pump on the surface of the sarcoplasmic reticulum-and induce the reloading of $\mathrm{Ca}^{2+}$ in action potentials (Rosano et al., 1999; Piquereau et al., 2010; Witayavanitkul et al., 2013). Modulation of SERCA levels or activity and $\mathrm{Ca}^{2+}$ burden by testosterone is suggested to be cardioprotective during ischemic events (Witayavanitkul et al., 2013). Additionally, it has been shown that estrogen can increase SERCA protein expression, particularly SERCA2b, which causes a decrease in intracellular $\mathrm{Ca}^{2+}$, thus increasing cell survival in coronary arteries (Witayavanitkul et al., 2013; Hill and Muldrew, 2014; Groban et al., 2019).

In cardiomycocytes, move phrase to after (CICR), the primary driver of $\mathrm{Ca}^{2+}$ release is through $\mathrm{Ca}^{2+}$ induced $\mathrm{Ca}^{2+}$ release (CICR). One example of a channel which exists in the inner mitochondrial membranes and the SR are the ryanodine receptors (RyR/mRyR), which are responsible for releasing intracellular stores of $\mathrm{Ca}^{2+}$ ions through CICR (Beutner et al., 2005; Altschafl et al., 2007; Gambardella et al., 2018). Leaky RyR on the SR has been directly implicated in heart failure, as excess cytosolic calcium is absorbed by mitochondria resulting in dysregulation and further RyR leak from oxidative damage generated by mitochondrial ROS
(Santulli et al., 2015). In contrast, when $\mathrm{Ca}^{2+}$ is released from inositol-triphosphate receptors $\left(\mathrm{IP}_{3} \mathrm{R}\right)$-receptors responsible for $\mathrm{Ca}^{2+}$ release and a mechanism for triggering CICRand absorbed by mitochondria, whose function, mitochondria or IP3R and ATP production increases; however, when mitochondria number is compromised-such as in heart failure, the $\mathrm{Ca}^{2+}$ release can induce arrhythmias (Hohendanner et al., 2015; Seidlmayer et al., 2016). The effect of estrogen on RyR expression and function is mixed and poorly understood, whereas growing evidence is implicating testosterone in increasing expression and function (Tsang et al., 2009; Hsu et al., 2015; Evanson et al., 2018; Groban et al., 2019; Mahmoodzadeh and Dworatzek, 2019; Jiao et al., 2020). For $\mathrm{IP}_{3} \mathrm{R}$, the role of estrogens is even more poorly understood, with some work implicating estrogen's ability to activate $\mathrm{IP}_{3}$ production in liver and smooth muscle cells, whereas testosterone has been shown to directly trigger $\mathrm{IP}_{3}$ production and $\mathrm{IP}_{3} \mathrm{R}$ activation in cardiomyocytes (Marino et al., 1998; Vicencio et al., 2006). In summary, these data suggest that the sex hormones play an important role in regulating intracellular $\mathrm{Ca}^{2+}$, itself a regulator of cellular apoptosis through the mitochondrion, thereby highlighting an additional cardioprotective role of the sex hormones (Pinton et al., 2008; Groban et al., 2019).

\section{CELL DEATH}

There is conflicting information regarding the role of the sex hormones in regulating cell death in cardiac tissue, and therefore,

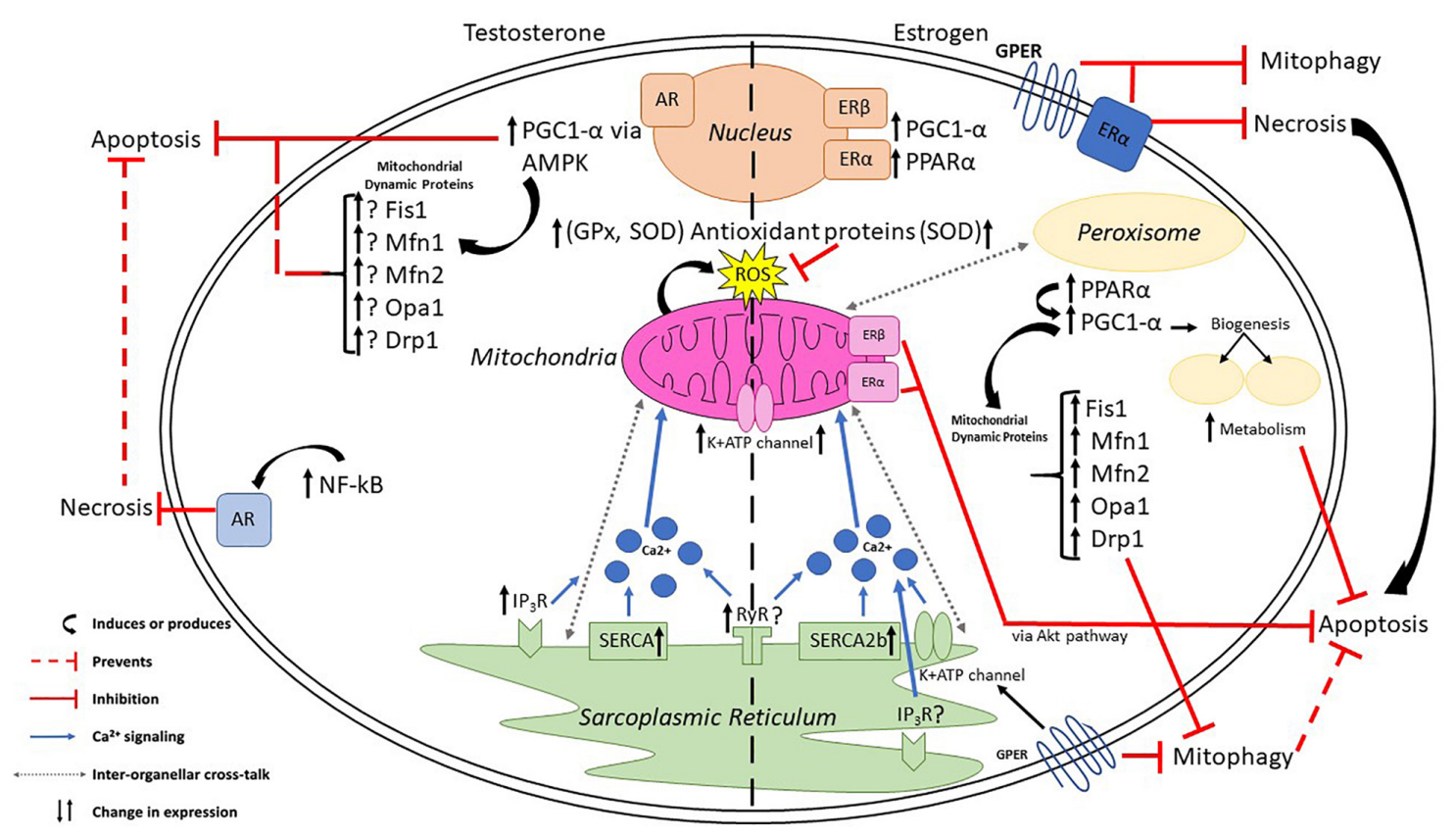

FIGURE 1 | Estrogen and testosterone influence mitochondrial dynamics and cross talk between organelles. Estrogen, via PPAR $\alpha$, upregulates PGC-1 $\alpha$ to initiate transcription of mitochondrial dynamic proteins and induce peroxisomal biogenesis. Testosterone upregulates PGC-1 $\alpha$, via AMPK, to influence mitochondrial dynamics. Both sex hormones increase antioxidant proteins to mitigate damaging reactive oxygen species, regulate $\mathrm{Ca}^{2+}$ signaling via $\mathrm{K}^{+} \mathrm{ATP}$ channels on the sarcoplasmic reticulum, and prevent various forms of cell death in CVD including apoptosis, necrosis, and mitophagy. 
indicated a need for further research in this area (Djouadi et al., 1998; Morris and Channer, 2012; Hsieh et al., 2015; Wang F. et al., 2015; Gagliano-Juca and Basaria, 2018; Jones and Kelly, 2018). Cell death pathways, including apoptosis, autophagy, necrosis, and pyroptosis, have been implicated in inducing cell death in CVD among various cell types within the heart including cardiomyocytes, endothelial cells, and monocytes/macrophages (Subramanian and Shaha, 2007; Wang F. et al., 2010; Chen et al., 2014; Feng et al., 2017; Amgalan et al., 2020; Di Florio et al., 2020). In macrophages, estrogen has been shown to regulate intracellular $\mathrm{Ca}^{2+}$ levels, which modulates Bcl-2 activity, and decreases Bax translocation to the mitochondria, thereby preserving cell viability through inhibition of intrinsic apoptosis (Subramanian and Shaha, 2007). Preliminary data in cardiomyocytes has shown that estrogen regulates Akt through $\mathrm{ER} \alpha$ which attenuates ROS-induced intrinsic apoptosis in female mice, but not males (Wang F. et al., 2010; Hevener et al., 2020). While the previous study determined $E R \beta$ does not play an anti-apoptotic role in response to ROS, estrogen signaling through $\operatorname{ER} \beta$ has been shown to decrease cardiac apoptosis by increasing mitochondrial Complex IV in rodent trauma-hemorrhage models (Hsieh et al., 2006). However, more recent studies have indicated that $\operatorname{ER} \beta$ is not highly expressed on cardiomyocytes, and therefore may not play a major cardioprotective role in CVD (Pugach et al., 2016; Groban et al., 2019).

Testosterone has been shown to indirectly regulate necrosis of cardiomyocytes through NF- $\kappa \mathrm{B}$ apoptotic signaling pathways, however, more studies on the regulation of cell death by testosterone are essential to better understand its role in CVD (Xiao et al., 2015). Estrogen and testosterone's roles in apoptosis may be altered according to receptor expression and cell type (Pugach et al., 2016). Therefore, further studies are necessary to better understand how signaling via both estrogen and testosterone influence cardiac apoptosis in CVD. Necrosis and pyroptosis are inflammatory cell death pathways regulated via caspase enzyme activity, which is induced when irreversible damage occurs in the tissues (Bergsbaken et al., 2009; Gao et al., 2019; Zhaolin et al., 2019). These pathways, more specifically, are initiated when the MPTP is damaged or uncontrolled in mitochondrial fission, as seen in CVD (Song et al., 2015; Amgalan et al., 2020). Estrogen treatment has been shown to inhibit necrosis and induce apoptosis in both sexes with lupus nephritis (Jog and Caricchio, 2013). In general, research on pyroptosis is limited in cardiac tissue and work has yet to indicate a direct role of the sex hormones.

\section{REFERENCES}

Acaz-Fonseca, E., Ortiz-Rodriguez, A., Garcia-Segura, L. M., and Astiz, M. (2020). Sex differences and gonadal hormone regulation of brain cardiolipin, a key mitochondrial phospholipid. J. Neuroendocrinol. 32:e12774. doi: 10.1111/jne. 12774

Altschafl, B. A., Beutner, G., Sharma, V. K., Sheu, S. S., and Valdivia, H. H. (2007). The mitochondrial ryanodine receptor in rat heart: a pharmaco-kinetic profile. Biochim. Biophys. Acta 1768, 1784-1795. doi: 10.1016/j.bbamem.2007.04.011

\section{CONCLUSION}

There are clinical disparities in CVD risk and incidence, which could be caused by known sexually dimorphic differences in cardiac cells and tissues. These differences are driven by the sex hormones-estrogen and testosterone-and the presence of their receptors $\mathrm{ER} \alpha, \mathrm{ER} \beta, \mathrm{GPER}$ and $\mathrm{AR}$, which are expressed differentially in varying organ systems and cell types. Studies have shown that both estrogen and testosterone can directly regulate mitochondrial biogenesis, ROS production, inter-organellar interactions between the mitochondria and the endoplasmic reticulum, in addition to preserving cell viability (Figure 1). Nevertheless, further studies are needed to better understand the exact mechanism of each sex hormone in regulating mitochondrial dynamics, specifically the regulation of mitochondrial fission and fusion proteins, so to establish differential function of each and elucidating the cause of CVD disparities between the sexes. Research on the cardioprotective effects of sex hormones has predominantly focused on estrogen, leaving much to be studied regarding testosterone's regulatory function in CVD. This review hopes to inspire others to begin focusing on the regulatory role of sex hormones in mitochondrial function and dynamics, as well as interorganellar cross talk.

\section{AUTHOR CONTRIBUTIONS}

SL wrote the mitochondrial dynamics section and metabolism, edited the manuscript, and created the Figure 1. JB wrote the section on cell death and $\mathrm{Ca}^{2+}$ regulation, created the Table 1, and reviewed the manuscript. MS compiled the sources for metabolism and dynamics, reviewed the manuscript, table, and figure. SG-M wrote the introduction and conclusion, edited the text, figures and table, and reviewed the final manuscript. All authors contributed to the article and approved the submitted version. MRS Co-wrote metabolism and $\mathrm{Ca}^{2+}$ sections, edited text, and reviewed the manuscript, table, and figure.

\section{FUNDING}

This work was supported by The Clinical and Diagnostic Sciences Program in the School of Health Professions.

Amgalan, D., Garner, T. P., Pekson, R., Jia, X. F., Yanamandala, M., Paulino, V., et al. (2020). A small-molecule allosteric inhibitor of BAX protects against doxorubicin-induced cardiomyopathy. Nat. Cancer 1, 315-328. doi: 10.1038/ s43018-020-0039-1

Araujo, A. B., and Wittert, G. A. (2011). Endocrinology of the aging male. Best Pract. Res. Clin. Endocrinol. Metab. 25, 303-319. doi: 10.1016/j.beem.2010. 11.004

Aronica, S. M., Kraus, W. L., and Katzenellenbogen, B. S. (1994). Estrogen action via the cAMP signaling pathway: stimulation of adenylate cyclase and 
cAMP-regulated gene transcription. Proc. Natl. Acad. Sci. U.S.A. 91, 8517-8521. doi: 10.1073/pnas.91.18.8517

Asmis, R., and Giordano-Mooga, S. (2020). Sexual dimorphisms in redox biology. Redox Biol. 31:101533. doi: 10.1016/j.redox.2020.101533

Azhary, J. M. K., Harada, M., Takahashi, N., Nose, E., Kunitomi, C., Koike, H., et al. (2018). Endoplasmic reticulum stress activated by androgen enhances apoptosis of granulosa cells via induction of death receptor 5 in PCOS. Endocrinology 160, 119-132. doi: 10.1210/en.2018-00675

Bagattin, A., Hugendubler, L., and Mueller, E. (2010). Transcriptional coactivator PGC-1alpha promotes peroxisomal remodeling and biogenesis. Proc. Natl. Acad. Sci. U.S.A. 107, 20376-20381. doi: 10.1073/pnas.1009176107

Ballantyne, T., Du, Q., Jovanović, S., Neemo, A., Holmes, R., Sinha, S., et al. (2013). Testosterone protects female embryonic heart $\mathrm{H} 9 \mathrm{c} 2$ cells against severe metabolic stress by activating estrogen receptors and up-regulating IES SUR2B. Int. J. Biochem. Cell Biol. 45, 283-291. doi: 10.1016/j.biocel.2012. 10.005

Barp, J., Araujo, A. S., Fernandes, T. R., Rigatto, K. V., Llesuy, S., Bello-Klein, A., et al. (2002). Myocardial antioxidant and oxidative stress changes due to sex hormones. Braz. J. Med. Biol. Res. 35, 1075-1081. doi: 10.1590/s0100879x2002000900008

Bayat, G., Javan, M., Safari, F., Khalili, A., Shokri, S., Goudarzvand, M., et al. (2016). Nandrolone decanoate negatively reverses the beneficial effects of exercise on cardiac muscle via sarcolemmal, but not mitochondrial K(ATP) channel. Can. J. Physiol. Pharmacol. 94, 324-331. doi: 10.1139/cjpp-2015-0040

Benten, W. P., Lieberherr, M., Giese, G., Wrehlke, C., Stamm, O., Sekeris, C. E., et al. (1999a). Functional testosterone receptors in plasma membranes of T cells. FASEB J. 13, 123-133. doi: 10.1096/fasebj.13.1.123

Benten, W. P., Lieberherr, M., Stamm, O., Wrehlke, C., Guo, Z., and Wunderlich, F. (1999b). Testosterone signaling through internalizable surface receptors in androgen receptor-free macrophages. Mol. Biol. Cell 10, 3113-3123. doi: 10. $1091 / \mathrm{mbc} .10 .10 .3113$

Bergsbaken, T., Fink, S. L., and Cookson, B. T. (2009). Pyroptosis: host cell death and inflammation. Nat. Rev. Microbiol. 7, 99-109. doi: 10.1038/nrmicro2070

Berridge, M. J. (2003). Cardiac calcium signalling. Biochem. Soc. Trans. 31(Pt 5), 930-933. doi: 10.1042/bst0310930

Beutner, G., Sharma, V. K., Lin, L., Ryu, S. Y., Dirksen, R. T., and Sheu, S. S. (2005). Type 1 ryanodine receptor in cardiac mitochondria: transducer of excitation-metabolism coupling. Biochim. Biophys. Acta 1717, 1-10. doi: 10. 1016/j.bbamem.2005.09.016

Bjorntorp, P. (1997). Body fat distribution, insulin resistance, and metabolic diseases. Nutrition 13, 795-803. doi: 10.1016/s0899-9007(97)00191-3

Bowling, M. R., Xing, D., Kapadia, A., Chen, Y. F., Szalai, A. J., Oparil, S., et al. (2014). Estrogen effects on vascular inflammation are age dependent: role of estrogen receptors. Arterioscler. Thromb. Vasc. Biol. 34, 1477-1485. doi: 10. 1161/ATVBAHA.114.303629

Brookes, P. S., Yoon, Y., Robotham, J. L., Anders, M. W., and Sheu, S. S. (2004). Calcium, ATP, and ROS: a mitochondrial love-hate triangle. Am. J. Physiol. Cell Physiol. 287, C817-C833. doi: 10.1152/ajpcell.00139.2004

Capllonch-Amer, G., Lladó, I., Proenza, A. M., García-Palmer, F. J., and Gianotti, M. (2014). Opposite effects of $17-\beta$ estradiol and testosterone on mitochondrial biogenesis and adiponectin synthesis in white adipocytes. J. Mol. Endocrinol. 52, 203-214. doi: 10.1530/jme-13-0201

Casin, K. M., and Kohr, M. J. (2020). An emerging perspective on sex differences: intersecting S-nitrosothiol and aldehyde signaling in the heart. Redox Biol. 31:101441. doi: 10.1016/j.redox.2020.101441

Chen, B. B., Coon, T. A., Glasser, J. R., Zou, C., Ellis, B., Das, T., et al. (2014). E3 ligase subunit Fbxo15 and PINK1 kinase regulate cardiolipin synthase 1 stability and mitochondrial function in pneumonia. Cell Rep. 7, 476-487. doi: 10.1016/j.celrep.2014.02.048

Chen, K. L., and Madak-Erdogan, Z. (2018). Estrogens and female liver health. Steroids 133, 38-43. doi: 10.1016/j.steroids.2017.10.015

Chen, Y., Csordas, G., Jowdy, C., Schneider, T. G., Csordas, N., Wang, W., et al. (2012). Mitofusin 2-containing mitochondrial-reticular microdomains direct rapid cardiomyocyte bioenergetic responses via interorganelle $\mathrm{Ca}(2+)$ crosstalk. Circ. Res. 111, 863-875. doi: 10.1161/CIRCRESAHA.112.266585

Cheng, S. B., Dong, J., Pang, Y., LaRocca, J., Hixon, M., Thomas, P., et al. (2014). Anatomical location and redistribution of $\mathrm{G}$ protein-coupled estrogen receptor1 during the estrus cycle in mouse kidney and specific binding to estrogens but not aldosterone. Mol. Cell Endocrinol. 382, 950-959. doi: 10.1016/j.mce.2013. 11.005

Clapham, D. E. (2007). Calcium signaling. Cell 131, 1047-1058. doi: 10.1016/j.cell. 2007.11.028

Cleland, W. H., Mendelson, C. R., and Simpson, E. R. (1985). Effects of aging and obesity on aromatase activity of human adipose cells. J. Clin. Endocrinol. Metab. 60, 174-177. doi: 10.1210/jcem-60-1-174

Consolini, A. E., Ragone, M. I., Bonazzola, P., and Colareda, G. A. (2017). Mitochondrial bioenergetics during ischemia and reperfusion. Adv. Exp. Med. Biol. 982, 141-167. doi: 10.1007/978-3-319-55330-6_8

Cruz-Topete, D., Dominic, P., and Stokes, K. Y. (2020). Uncovering sex-specific mechanisms of action of testosterone and redox balance. Redox Biol. 31:101490. doi: 10.1016/j.redox.2020.101490

Dart, D. A., Waxman, J., Aboagye, E. O., and Bevan, C. L. (2013). Visualising androgen receptor activity in male and female mice. PLoS One 8:e71694. doi: 10.1371/journal.pone.0071694

Das, A. M., and Harris, D. A. (1990). Control of mitochondrial ATP synthase in heart cells: inactive to active transitions caused by beating or positive inotropic agents. Cardiovasc. Res. 24, 411-417. doi: 10.1093/cvr/24.5.411

Davey, R. A., and Grossmann, M. (2016). Androgen receptor structure. Function and biology: from bench to bedside. Clin. Biochem. Rev. 37, 3-15.

Dedkova, E. N., and Blatter, L. A. (2012). Measuring mitochondrial function in intact cardiac myocytes. J. Mol. Cell Cardiol. 52, 48-61. doi: 10.1016/j.yjmcc. 2011.08.030

Deroo, B. J., and Korach, K. S. (2006). Estrogen receptors and human disease. J. Clin. Invest. 116, 561-570. doi: 10.1172/JCI27987

Di Florio, D. N., Sin, J., Coronado, M. J., Atwal, P. S., and Fairweather, D. (2020). Sex differences in inflammation, redox biology, mitochondria and autoimmunity. Redox Biol. 31:101482. doi: 10.1016/j.redox.2020. 101482

Djouadi, F., Weinheimer, C. J., Saffitz, J. E., Pitchford, C., Bastin, J., Gonzalez, F. J., et al. (1998). A gender-related defect in lipid metabolism and glucose homeostasis in peroxisome proliferator- activated receptor alpha- deficient mice. J. Clin. Invest. 102, 1083-1091. doi: 10.1172/JCI3949

Doan, K. N., Grevel, A., Martensson, C. U., Ellenrieder, L., Thornton, N., Wenz, L. S., et al. (2020). The mitochondrial import complex MIM functions as main translocase for alpha-helical outer membrane proteins. Cell Rep. 31:107567. doi: 10.1016/j.celrep.2020.107567

Dorn, G. II (2016). Mitochondrial fission/fusion and cardiomyopathy. Curr. Opin. Genet. Dev. 38, 38-44. doi: 10.1016/j.gde.2016.03.001

Dorn, G. W. II, Vega, R. B., and Kelly, D. P. (2015). Mitochondrial biogenesis and dynamics in the developing and diseased heart. Genes Dev. 29, 1981-1991. doi: 10.1101/gad.269894.115

Elagizi, A., Kohler, T. S., and Lavie, C. J. (2018). Testosterone and cardiovascular health. Mayo Clin. Proc. 93, 83-100. doi: 10.1016/j.mayocp.2017.11.006

Ellenrieder, L., Martensson, C. U., and Becker, T. (2015). Biogenesis of mitochondrial outer membrane proteins, problems and diseases. Biol. Chem. 396, 1199-1213. doi: 10.1515/hsz-2015-0170

Ellenrieder, L., Rampelt, H., and Becker, T. (2017). Connection of protein transport and organelle contact sites in mitochondria. J. Mol. Biol. 429, 2148-2160. doi: 10.1016/j.jmb.2017.05.023

Er, F., Michels, G., Gassanov, N., Rivero, F., and Hoppe Uta, C. (2004). Testosterone induces cytoprotection by activating ATP-Sensitive $\mathrm{K}+$ channels in the cardiac mitochondrial inner membrane. Circulation 110, 3100-3107. doi: 10.1161/01. CIR.0000146900.84943.E0

Erlandsson, M. C., Ohlsson, C., Gustafsson, J. A., and Carlsten, H. (2001). Role of oestrogen receptors alpha and beta in immune organ development and in oestrogen-mediated effects on thymus. Immunology 103, 17-25. doi: 10.1046/j. 1365-2567.2001.01212.x

Evanson, K. W., Goldsmith, J. A., Ghosh, P., and Delp, M. D. (2018). The G proteincoupled estrogen receptor agonist, G-1, attenuates BK channel activation in cerebral arterial smooth muscle cells. Pharmacol. Res. Perspect. 6:e00409. doi: $10.1002 /$ prp2.409

Feng, Y., Madungwe, N. B., da Cruz Junho, C. V., and Bopassa, J. C. (2017). Activation of $\mathrm{G}$ protein-coupled oestrogen receptor 1 at the onset of reperfusion protects the myocardium against ischemia/reperfusion injury by reducing mitochondrial dysfunction and mitophagy. Br. J. Pharmacol. 174, 4329-4344. doi: $10.1111 /$ bph.14033 
Filardo, E. J., Quinn, J. A., Bland, K. I., and Frackelton, A. R. Jr. (2000). Estrogeninduced activation of Erk-1 and Erk-2 requires the G protein-coupled receptor homolog, GPR30, and occurs via trans-activation of the epidermal growth factor receptor through release of HB-EGF. Mol. Endocrinol. 14, 1649-1660. doi: $10.1210 /$ mend.14.10.0532

Freeman, E. W., Sammel, M. D., Lin, H., and Gracia, C. R. (2010). Obesity and reproductive hormone levels in the transition to menopause. Menopause 17, 718-726. doi: 10.1097/gme.0b013e3181cec85d

Fui, M. N., Dupuis, P., and Grossmann, M. (2014). Lowered testosterone in male obesity: mechanisms, morbidity and management. Asian J. Androl. 16, 223-231. doi: 10.4103/1008-682X.122365

Gagliano-Juca, T., and Basaria, S. (2018). Trials of testosterone replacement reporting cardiovascular adverse events. Asian J. Androl. 20, 131-137. doi: 10.4103/aja.aja_28_17

Gambardella, J., Trimarco, B., Iaccarino, G., and Santulli, G. (2018). New insights in cardiac calcium handling and excitation-contraction coupling. Adv. Exp. Med. Biol. 1067, 373-385. doi: 10.1007/5584_2017_106

Gao, J., Xu, D., Sabat, G., Valdivia, H., Xu, W., and Shi, N.-Q. (2014). Disrupting KATP channels diminishes the estrogen-mediated protection in female mutant mice during ischemia-reperfusion. Clin. Proteomics 11:19. doi: 10.1186/15590275-11-19

Gao, J., Zhao, L., Wang, J., Zhang, L., Zhou, D., Qu, J., et al. (2019). C-Phycocyanin ameliorates mitochondrial fission and fusion dynamics in ischemic cardiomyocyte damage. Front. Pharmacol. 10:733. doi: 10.3389/fphar. 2019.00733

Gourdy, P., Guillaume, M., Fontaine, C., Adlanmerini, M., Montagner, A., Laurell, H., et al. (2018). Estrogen receptor subcellular localization and cardiometabolism. Mol. Metab. 15, 56-69. doi: 10.1016/j.molmet.2018.05.009

Groban, L., Tran, Q. K., Ferrario, C. M., Sun, X., Cheng, C. P., Kitzman, D. W., et al. (2019). Female heart health: is GPER the missing link? Front. Endocrinol. 10:919. doi: 10.3389/fendo.2019.00919

Hanke, H., Lenz, C., Hess, B., Spindler, K.-D., and Weidemann, W. (2001). Effect of testosterone on plaque development and androgen receptor expression in the arterial vessel wall. Circulation 103, 1382-1385. doi: 10.1161/01.CIR.103.10. 1382

Hevener, A. L., Ribas, V., Moore, T. M., and Zhou, Z. (2020). The impact of skeletal muscle ERalpha on mitochondrial function and metabolic health. Endocrinology 161:bqz017. doi: 10.1210/endocr/bqz017

Hill, B. J., and Muldrew, E. (2014). Oestrogen upregulates the sarcoplasmic reticulum $\mathrm{Ca}(2+)$ ATPase pump in coronary arteries. Clin. Exp. Pharmacol. Physiol. 41, 430-436. doi: 10.1111/1440-1681. 12233

Hodis, H. N., and Mack, W. J. (2014). Hormone replacement therapy and the association with coronary heart disease and overall mortality: clinical application of the timing hypothesis. J. Steroid. Biochem. Mol. Biol. 142, 68-75. doi: 10.1016/j.jsbmb.2013.06.011

Hohendanner, F., Walther, S., Maxwell, J. T., Kettlewell, S., Awad, S., Smith, G. L., et al. (2015). Inositol-1,4,5-trisphosphate induced Ca2+ release and excitation-contraction coupling in atrial myocytes from normal and failing hearts. J. Physiol. 593, 1459-1477. doi: 10.1113/jphysiol.2014. 283226

Horard, B., and Vanacker, J. M. (2003). Estrogen receptor-related receptors: orphan receptors desperately seeking a ligand. J. Mol. Endocrinol. 31, 349-357. doi: 10.1677/jme.0.0310349

Hsieh, D. J. Y., Kuo, W. W., Lai, Y. P., Shibu, M. A., Shen, C. Y., Pai, P., et al. (2015). 17 $\beta$-Estradiol and/or estrogen receptor $\beta$ Attenuate the autophagic and apoptotic effects induced by prolonged hypoxia through HIF-1 $\alpha$-Mediated BNIP3 and IGFBP-3 signaling blockage. Cell. Physiol. Biochem. 36, 274-284. doi: 10.1159/000374070

Hsieh, Y. C., Yu, H. P., Suzuki, T., Choudhry, M. A., Schwacha, M. G., Bland, K. I., et al. (2006). Upregulation of mitochondrial respiratory complex IV by estrogen receptor-beta is critical for inhibiting mitochondrial apoptotic signaling and restoring cardiac functions following trauma-hemorrhage. J. Mol. Cell Cardiol. 41, 511-521. doi: 10.1016/j.yjmcc.2006.06.001

Hsu, J.-C., Cheng, C.-C., Kao, Y.-H., Chen, Y.-C., Chung, C.-C., and Chen, Y.J. (2015). Testosterone regulates cardiac calcium homeostasis with enhanced ryanodine receptor 2 expression through activation of TGF- $\beta$. Int. J. Cardiol. 190, 11-14. doi: 10.1016/j.ijcard.2015.04.116
Hu, J., Zhang, Z., Shen, W. J., and Azhar, S. (2010). Cellular cholesterol delivery, intracellular processing and utilization for biosynthesis of steroid hormones. Nutr. Metab. 7:47. doi: 10.1186/1743-7075-7-47

Huang, C.-K., Lee, S. O., Chang, E., Pang, H., and Chang, C. (2016). Androgen receptor (AR) in cardiovascular diseases. J. Endocrinol. 229, R1-R16. doi: 10. 1530/JOE-15-0518

Huang, T.-Y., Zheng, D., Hickner, R. C., Brault, J. J., and Cortright, R. N. (2019). Peroxisomal gene and protein expression increase in response to a high-lipid challenge in human skeletal muscle. Metab. Clin. Exp. 98, 53-61. doi: 10.1016/j. metabol.2019.06.009

Huang, T.-Y., Zheng, D., Houmard, J. A., Brault, J. J., Hickner, R. C., and Cortright, R. N. (2017). Overexpression of PGC-1 $\alpha$ increases peroxisomal activity and mitochondrial fatty acid oxidation in human primary myotubes. Am. J. Physiol. 312, E253-E263. doi: 10.1152/ajpendo.00331.2016

Huss, J. M., Torra, I. P., Staels, B., Giguère, V., and Kelly, D. P. (2004). Estrogenrelated receptor alpha directs peroxisome proliferator-activated receptor alpha signaling in the transcriptional control of energy metabolism in cardiac and skeletal muscle. Mol. Cell Biol. 24, 9079-9091. doi: 10.1128/mcb.24.20.90799091.2004

Hutson, D. D., Gurrala, R., Ogola, B. O., Zimmerman, M. A., Mostany, R., Satou, R., et al. (2019). Estrogen receptor profiles across tissues from male and female Rattus norvegicus. Biol. Sex. Differ. 10:4. doi: 10.1186/s13293-019-0219-9

Ikeda, Y., Aihara, K., Sato, T., Akaike, M., Yoshizumi, M., Suzaki, Y., et al. (2005). Androgen receptor gene knockout male mice exhibit impaired cardiac growth and exacerbation of angiotensin II-induced cardiac fibrosis. J. Biol. Chem. 280, 29661-29666. doi: 10.1074/jbc.M411694200

Improta-Brears, T., Whorton, A. R., Codazzi, F., York, J. D., Meyer, T., and McDonnell, D. P. (1999). Estrogen-induced activation of mitogen-activated protein kinase requires mobilization of intracellular calcium. Proc. Natl. Acad. Sci. U.S.A. 96, 4686-4691. doi: 10.1073/pnas.96.8.4686

Ishihara, N., Nomura, M., Jofuku, A., Kato, H., Suzuki, S. O., Masuda, K., et al. (2009). Mitochondrial fission factor Drp1 is essential for embryonic development and synapse formation in mice. Nat. Cell Biol. 11, 958-966. doi: $10.1038 /$ ncb1907

Iyengar, N. M., Brown, K. A., Zhou, X. K., Gucalp, A., Subbaramaiah, K., Giri, D. D., et al. (2017). Metabolic obesity, adipose inflammation and elevated breast aromatase in women with normal body mass index. Cancer Prev. Res. 10, 235-243. doi: 10.1158/1940-6207.CAPR-16-0314

Jiao, L., Machuki, J. O. A., Wu, Q., Shi, M., Fu, L., Adekunle, A. O., et al. (2020). Estrogen and calcium handling proteins: new discoveries and mechanisms in cardiovascular diseases. Am. J. Physiol. Heart Circ. Physiol. 318, H820-H829. doi: 10.1152/ajpheart.00734.2019

Jog, N. R., and Caricchio, R. (2013). Differential regulation of cell death programs in males and females by Poly (ADP-Ribose) Polymerase-1 and 17beta estradiol. Cell Death Dis. 4:e758. doi: 10.1038/cddis.2013.251

Jones, T. H., and Kelly, D. M. (2018). Randomized controlled trials - mechanistic studies of testosterone and the cardiovascular system. Asian J. Androl. 20, 120-130. doi: 10.4103/aja.aja_6_18

Jornayvaz, F. R., and Shulman, G. I. (2010). Regulation of mitochondrial biogenesis. Essays Biochem. 47, 69-84. doi: 10.1042/bse0470069

Keller, K. M., and Howlett, S. E. (2016). Sex differences in the biology and pathology of the aging heart. Can. J. Cardiol. 32, 1065-1073. doi: 10.1016/j.cjca.2016.03. 017

Kerkhofs, S., Denayer, S., Haelens, A., and Claessens, F. (2009). Androgen receptor knockout and knock-in mouse models. J. Mol. Endocrinol. 42, 11-17. doi: 10.1677/JME-08-0122

Khoury, S., Yarows, S. A., O’Brien, T. K., and Sowers, J. R. (1992). Ambulatory blood pressure monitoring in a nonacademic setting. Effects of age and sex. Am. J. Hypertens. 5, 616-623. doi: 10.1093/ajh/5.9.616

Klinge, C. M. (2008). Estrogenic control of mitochondrial function and biogenesis. J. Cell. Biochem. 105, 1342-1351. doi: 10.1002/jcb.21936

Krzywanski, D. M., Moellering, D. R., Fetterman, J. L., Dunham-Snary, K. J., Sammy, M. J., and Ballinger, S. W. (2011). The mitochondrial paradigm for cardiovascular disease susceptibility and cellular function: a complementary concept to Mendelian genetics. Lab Invest. 91, 1122-1135. doi: 10.1038/ labinvest.2011.95

Lai, L., Leone, T. C., Zechner, C., Schaeffer, P. J., Kelly, S. M., Flanagan, D. P., et al. (2008). Transcriptional coactivators PGC-1alpha and PGC-lbeta control 
overlapping programs required for perinatal maturation of the heart. Genes Dev. 22, 1948-1961. doi: 10.1101/gad.1661708

Lee, J., Giordano, S., and Zhang, J. (2012). Autophagy, mitochondria and oxidative stress: cross-talk and redox signalling. Biochem. J. 441, 523-540. doi: 10.1042/ BJ20111451

Lee, S. R., and Han, J. (2017). Mitochondrial nucleoid: shield and switch of the mitochondrial genome. Oxid. Med. Cell Longev. 2017:8060949. doi: 10.1155/ 2017/8060949

Lee, Y. G., Nam, Y., Shin, K. J., Yoon, S., Park, W. S., Joung, J. Y., et al. (2020). Androgen-induced expression of DRP1 regulates mitochondrial metabolic reprogramming in prostate cancer. Cancer Lett. 471, 72-87. doi: 10.1016/j. canlet.2019.12.017

Leeners, B., Geary, N., Tobler, P. N., and Asarian, L. (2017). Ovarian hormones and obesity. Hum. Reprod. Update 23, 300-321. doi: 10.1093/humupd/dmw045

Lejri, I., Grimm, A., and Eckert, A. (2018). Mitochondria, estrogen and female brain aging. Front. Aging Neurosci. 10:124. doi: 10.3389/fnagi.2018.00124

Levin, E. R. (2009). Plasma membrane estrogen receptors. Trends Endocrinol. Metab. 20, 477-482. doi: 10.1016/j.tem.2009.06.009

Li, H., Liu, Z., Gou, Y., Yu, H., Siminelakis, S., Wang, S., et al. (2015). Estradiol mediates vasculoprotection via ERRalpha-dependent regulation of lipid and ROS metabolism in the endothelium. J. Mol. Cell Cardiol. 87, 92-101. doi: 10.1016/j.yjmcc.2015.08.008

Li, L., Haynes, M. P., and Bender, J. R. (2003). Plasma membrane localization and function of the estrogen receptor alpha variant (ER46) in human endothelial cells. Proc. Natl. Acad. Sci. U.S.A. 100, 4807-4812. doi: 10.1073/ pnas. 0831079100

Liang, H., and Ward, W. F. (2006). PGC-1alpha: a key regulator of energy metabolism. Adv. Physiol. Educ. 30, 145-151. doi: 10.1152/advan.00052.2006

Liu, Z., Gou, Y., Zhang, H., Zuo, H., Zhang, H., Liu, Z., et al. (2014). Estradiol improves cardiovascular function through up-regulation of SOD2 on vascular wall. Redox Biol. 3, 88-99. doi: 10.1016/j.redox.2014.11.001

Liu, H., Yanamandala, M., Lee, T. C., and Kim, J. K. (2014). Mitochondrial p38beta and manganese superoxide dismutase interaction mediated by estrogen in cardiomyocytes. PLoS One 9:e85272. doi: 10.1371/journal.pone.0085272

Lizotte, E., Grandy, S. A., Tremblay, A., Allen, B. G., and Fiset, C. (2009). Expression, distribution and regulation of sex steroid hormone receptors in mouse heart. Cell. Physiol. Biochem. 23, 075-086. doi: 10.1159/000204096

Lone, M. U., Baghel, K. S., Kanchan, R. K., Shrivastava, R., Malik, S. A., Tewari, B. N., et al. (2017). Physical interaction of estrogen receptor with MnSOD: implication in mitochondrial $\mathrm{O}(2)(.-)$ upregulation and mTORC2 potentiation in estrogen-responsive breast cancer cells. Oncogene 36, 1829-1839. doi: 10. 1038/onc.2016.346

Lou, Q., Janardhan, A., and Efimov, I. R. (2012). Remodeling of calcium handling in human heart failure. Adv. Exp. Med. Biol. 740, 1145-1174. doi: 10.1007/97894-007-2888-2_52

Luo, T., and Kim, J. K. (2016). The role of estrogen and estrogen receptors on cardiomyocytes: an overview. Can. J. Cardiol. 32, 1017-1025. doi: 10.1016/j. cjca.2015.10.021

Mahmoodzadeh, S., and Dworatzek, E. (2019). The role of 17beta-Estradiol and estrogen receptors in regulation of $\mathrm{Ca}(2+)$ channels and mitochondrial function in cardiomyocytes. Front. Endocrinol. 10:310. doi: 10.3389/fendo.2019.00310

Marino, M., Pallottini, V., and Trentalance, A. (1998). Estrogens cause rapid activation of IP3-PKC-alpha signal transduction pathway in HEPG2 cells. Biochem. Biophys. Res. Commun. 245, 254-258. doi: 10.1006/bbrc.1998.8413

Marsh James, D., Lehmann Michael, H., Ritchie Rebecca, H., Gwathmey Judith, K., Green Glenn, E., and Schiebinger Rick, J. (1998). Androgen receptors mediate hypertrophy in cardiac myocytes. Circulation 98, 256-261. doi: 10.1161/01.CIR. 98.3.256

Martin, J. O., Lai, M. L., Soundarapandian, C. M., Leone, P. T., Zorzano, D. A., Keller, M. M., et al. (2014). A role for peroxisome proliferator-activated Receptor $\gamma$ Coactivator-1 in the control of mitochondrial dynamics during postnatal cardiac growth. Circ. Res. 114, 626-636. doi: 10.1161/CIRCRESAHA. 114.302562

McCormack, J. G., Halestrap, A. P., and Denton, R. M. (1990). Role of calcium ions in regulation of mammalian intramitochondrial metabolism. Physiol. Rev. 70, 391-425. doi: 10.1152/physrev.1990.70.2.391

Mercado, C. I., Yang, Q., Ford, E. S., Gregg, E., and Valderrama, A. L. (2015). Gender- and race-specific metabolic score and cardiovascular disease mortality in adults: a structural equation modeling approach-United States, 1988-2006. Obesity 23, 1911-1919. doi: 10.1002/oby.21171

Miller, W. L. (2013). Steroid hormone synthesis in mitochondria. Mol. Cell Endocrinol. 379, 62-73. doi: 10.1016/j.mce.2013.04.014

Miller, W. L., and Bose, H. S. (2011). Early steps in steroidogenesis: intracellular cholesterol trafficking. J. Lipid Res. 52, 2111-2135. doi: 10.1194/jlr.R016675

Moore, J. X., Chaudhary, N., and Akinyemiju, T. (2017). Metabolic syndrome prevalence by race/ethnicity and sex in the United States, national health and nutrition examination survey, 1988-2012. Prev. Chronic. Dis. 14:E24. doi: 10. 5888/pcd14.160287

Morris, P. D., and Channer, K. S. (2012). Testosterone and cardiovascular disease in men. Asian J. Androl. 14, 428-435. doi: 10.1038/aja.2012.21

Nöhammer, C., Brunner, F., Wölkart, G., Staber, P. B., Steyrer, E., Gonzalez, F. J., et al. (2003). Myocardial dysfunction and male mortality in peroxisome proliferator-activated receptor alpha knockout mice overexpressing lipoprotein lipase in muscle. Lab. Invest. 83, 259-269. doi: 10.1097/01.LAB.0000053916. 61772.CA

Ogola, B. O., Zimmerman, M. A., Sure, V. N., Gentry, K. M., Duong, J. L., Clark, G. L., et al. (2019). G Protein-coupled estrogen receptor protects from angiotensin ii-induced increases in pulse pressure and oxidative stress. Front. Endocrinol. 10:586. doi: 10.3389/fendo.2019.00586

Ong, S. B., Subrayan, S., Lim, S. Y., Yellon, D. M., Davidson, S. M., and Hausenloy, D. J. (2010). Inhibiting mitochondrial fission protects the heart against ischemia/reperfusion injury. Circulation 121, 2012-2022. doi: 10.1161/ CIRCULATIONAHA.109.906610

Papanicolaou, K. N., Kikuchi, R., Ngoh, G. A., Coughlan, K. A., Dominguez, I., Stanley, W. C., et al. (2012). Mitofusins 1 and 2 are essential for postnatal metabolic remodeling in heart. Circ. Res. 111, 1012-1026. doi: 10.1161/ CIRCRESAHA.112.274142

Park, Y.-M., Pereira, R. I., Erickson, C. B., Swibas, T. A., Kang, C., and Van Pelt, R. E. (2017). Time since menopause and skeletal muscle estrogen receptors. PGC-1 $\alpha$, and AMPK. Menopause 24, 815-823. doi: 10.1097/GME. 0000000000000829

Parra, V., Eisner, V., Chiong, M., Criollo, A., Moraga, F., Garcia, A., et al. (2008). Changes in mitochondrial dynamics during ceramide-induced cardiomyocyte early apoptosis. Cardiovasc. Res. 77, 387-397. doi: 10.1093/cvr/cvm029

Pedernera, E., Gómora, M. J., Meneses, I., De Ita, M., and Méndez, C. (2017). Androgen receptor is expressed in mouse cardiomyocytes at prenatal and early postnatal developmental stages. BMC Physiol. 17:7. doi: 10.1186/s12899-0170033-8

Pfanner, N., and Meijer, M. (1997). The tom and tim machine. Curr. Biol. 7, R100-R103. doi: 10.1016/s0960-9822(06)00048-0

Pinton, P., Giorgi, C., Siviero, R., Zecchini, E., and Rizzuto, R. (2008). Calcium and apoptosis: ER-mitochondria $\mathrm{Ca} 2+$ transfer in the control of apoptosis. Oncogene 27, 6407-6418. doi: 10.1038/onc.2008.308

Piquereau, J., Caffin, F., Novotova, M., Prola, A., Garnier, A., Mateo, P., et al. (2012). Down-regulation of OPA1 alters mouse mitochondrial morphology, PTP function, and cardiac adaptation to pressure overload. Cardiovasc. Res. 94, 408-417. doi: 10.1093/cvr/cvs117

Piquereau, J., Novotova, M., Fortin, D., Garnier, A., Ventura-Clapier, R., Veksler, V., et al. (2010). Postnatal development of mouse heart: formation of energetic microdomains. J. Physiol. 588(Pt 13), 2443-2454. doi: 10.1113/jphysiol.2010. 189670

Pozdniakova, S., Guitart-Mampel, M., Garrabou, G., Di Benedetto, G., Ladilov, Y., and Regitz-Zagrosek, V. (2018). 17beta-Estradiol reduces mitochondrial cAMP content and cytochrome oxidase activity in a phosphodiesterase 2dependent manner. Br. J. Pharmacol. 175, 3876-3890. doi: 10.1111/bph. 14455

Pugach, E. K., Blenck, C. L., Dragavon, J. M., Langer, S. J., and Leinwand, L. A. (2016). Estrogen receptor profiling and activity in cardiac myocytes. Mol. Cell Endocrinol. 431, 62-70. doi: 10.1016/j.mce.2016.05.004

Ranki, H. J., Budas, G. R., Crawford, R. M., Davies, A. M., and Jovanovic, A. (2002). 17Beta-estradiol regulates expression of K(ATP) channels in heartderived H9c2 cells. J. Am. Coll Cardiol. 40, 367-374. doi: 10.1016/s07351097(02)01947-2

Redmann, M., Dodson, M., Boyer-Guittaut, M., Darley-Usmar, V., and Zhang, J. (2014). Mitophagy mechanisms and role in human diseases. Int. J. Biochem. Cell Biol. 53, 127-133. doi: 10.1016/j.biocel.2014.05.010 
Rosano, G. M. C., Leonardo, F., Pagnotta, P., Pelliccia, F., Panina, G., Cerquetani, E., et al. (1999). Acute anti-ischemic effect of testosterone in men with coronary artery disease. Circulation 99, 1666-1670. doi: 10.1161/01.CIR.99.13.1666

Rossouw, J. E., Anderson, G. L., Prentice, R. L., LaCroix, A. Z., Kooperberg, C., Stefanick, M. L., et al. (2002). Risks and benefits of estrogen plus progestin in healthy postmenopausal women: principal results From the Women's Health Initiative randomized controlled trial. JAMA 288, 321-333. doi: 10.1001/jama. 288.3.321

Sakamoto, K., and Kurokawa, J. (2019). Involvement of sex hormonal regulation of $\mathrm{K}+$ channels in electrophysiological and contractile functions of muscle tissues. J. Pharmacol. Sci. 139, 259-265. doi: 10.1016/j.jphs.2019.02.009

Samavat, H., and Kurzer, M. S. (2015). Estrogen metabolism and breast cancer. Cancer Lett. 356(2 Pt A), 231-243. doi: 10.1016/j.canlet.2014.04.018

Sandstede, J., Lipke, C., Beer, M., Hofmann, S., Pabst, T., Kenn, W., et al. (2000). Age- and gender-specific differences in left and right ventricular cardiac function and mass determined by cine magnetic resonance imaging. Eur. Radiol. 10, 438-442. doi: 10.1007/s003300050072

Santulli, G., Xie, W., Reiken, S. R., and Marks, A. R. (2015). Mitochondrial calcium overload is a key determinant in heart failure. Proc. Natl. Acad. Sci. U.S.A. 112, 11389-11394. doi: 10.1073/pnas.1513047112

Sastre-Serra, J., Nadal-Serrano, M., Pons, D. G., Roca, P., and Oliver, J. (2013). ). The over-expression of ERbeta modifies estradiol effects on mitochondrial dynamics in breast cancer cell line. Int. J. Biochem. Cell Biol. 45, 1509-1515. doi: 10.1016/j.biocel.2013.04.007

Sbert-Roig, M., Bauza-Thorbrugge, M., Galmes-Pascual, B. M., Capllonch-Amer, G., Garcia-Palmer, F. J., Llado, I., et al. (2016). GPER mediates the effects of 17 beta-estradiol in cardiac mitochondrial biogenesis and function. Mol. Cell Endocrinol. 420, 116-124. doi: 10.1016/j.mce.2015.11.027

Schrader, M., Bonekamp, N. A., and Islinger, M. (2012). Fission and proliferation of peroxisomes. Biochim. Biophys. Acta 1822, 1343-1357. doi: 10.1016/j.bbadis. 2011.12.014

Schrader, M., and Fahimi, H. D. (2006). Peroxisomes and oxidative stress. Biochim. Biophys. Acta 1763, 1755-1766. doi: 10.1016/j.bbamcr.2006.09.006

Segawa, T., Nau, M. E., Xu, L. L., Chilukuri, R. N., Makarem, M., Zhang, W., et al. (2002). Androgen-induced expression of endoplasmic reticulum (ER) stress response genes in prostate cancer cells. Oncogene 21, 8749-8758. doi: 10.1038/sj.onc. 1205992

Seidlmayer, L. K., Kuhn, J., Berbner, A., Arias-Loza, P.-A., Williams, T., Kaspar, M., et al. (2016). Inositol 1,4,5-trisphosphate-mediated sarcoplasmic reticulummitochondrial crosstalk influences adenosine triphosphate production via mitochondrial $\mathrm{Ca} 2+$ uptake through the mitochondrial ryanodine receptor in cardiac myocytes. Cardiovasc. Res. 112, 491-501. doi: 10.1093/cvr/ cvw185

Shirihai, O. S., Song, M., and Dorn, G. W. II (2015). How mitochondrial dynamism orchestrates mitophagy. Circ. Res. 116, 1835-1849. doi: 10.1161/CIRCRESAHA. 116.306374

Siasos, G., Tsigkou, V., Kosmopoulos, M., Theodosiadis, D., Simantiris, S., Tagkou, N. M., et al. (2018). Mitochondria and cardiovascular diseases-from pathophysiology to treatment. Ann. Transl. Med. 6:256. doi: 10.21037/atm.2018. 06.21

Song, M., Mihara, K., Chen, Y., Scorrano, L., and Dorn, G. W. II (2015). Mitochondrial fission and fusion factors reciprocally orchestrate mitophagic culling in mouse hearts and cultured fibroblasts. Cell Metab. 21, 273-286. doi: 10.1016/j.cmet.2014.12.011

Stampfer, M. J., Colditz, G. A., Willett, W. C., Manson, J. E., Rosner, B., Speizer, F. E., et al. (1991). Postmenopausal estrogen therapy and cardiovascular disease. Ten-year follow-up from the nurses' health study. N. Engl. J. Med. 325, 756-762. doi: 10.1056/NEJM199109123251102

Strehlow, K., Rotter, S., Wassmann, S., Adam, O., Grohe, C., Laufs, K., et al. (2003). Modulation of antioxidant enzyme expression and function by estrogen. Circ. Res. 93, 170-177. doi: 10.1161/01.RES.0000082334. 17947.11

Subramanian, M., and Shaha, C. (2007). Up-regulation of Bcl-2 through ERK phosphorylation is associated with human macrophage survival in an estrogen microenvironment. J. Immunol. 179, 2330-2338. doi: 10.4049/jimmunol.179.4. 2330

Sun, L., Zhao, M., Yu, X. J., Wang, H., He, X., Liu, J. K., et al. (2013). Cardioprotection by acetylcholine: a novel mechanism via mitochondrial biogenesis and function involving the PGC-1alpha pathway. J. Cell Physiol. 228, 1238-1248. doi: 10.1002/jcp.24277

Terrazas, S., Brashear, L., Escoto, A.-K., Lynch, S., Slaughter, D., Xavier, N., et al. (2019). Sex Differences in Obesity-Induced Inflammation. London: IntechOpen. Tsang, S., Wong, S. S. C., Wu, S., Kravtsov, G. M., and Wong, T.-M. (2009). Testosterone-augmented contractile responses to $\alpha 1$ - and $\beta 1$-adrenoceptor stimulation are associated with increased activities of RyR, SERCA, and NCX in the heart. Am. J. f Physiol. Cell Physiol. 296, C766-C782. doi: 10.1152/ajpcell. 00193.2008

Van Pelt, R. E., Gavin, K. M., and Kohrt, W. M. (2015). Regulation of body composition and bioenergetics by estrogens. Endocrinol. Metab. Clin. North Am. 44, 663-676. doi: 10.1016/j.ecl.2015. 05.011

Varanita, T., Soriano, M. E., Romanello, V., Zaglia, T., Quintana-Cabrera, R., Semenzato, M., et al. (2015). The OPA1-dependent mitochondrial cristae remodeling pathway controls atrophic, apoptotic, and ischemic tissue damage. Cell Metab. 21, 834-844. doi: 10.1016/j.cmet.2015. 05.007

Ventura-Clapier, R., Moulin, M., Piquereau, J., Lemaire, C., Mericskay, M., Veksler, V., et al. (2017). Mitochondria: a central target for sex differences in pathologies. Clin. Sci. 131, 803-822. doi: 10.1042/CS20160485

Ventura-Clapier, R., Piquereau, J., Veksler, V., and Garnier, A. (2019). Estrogens, estrogen receptors effects on cardiac and skeletal muscle mitochondria. Front. Endocrinol. 10:557. doi: 10.3389/fendo.2019. 00557

Vicencio, J. M., Ibarra, C., Estrada, M., Chiong, M., Soto, D., Parra, V., et al. (2006). Testosterone induces an intracellular calcium increase by a nongenomic mechanism in cultured rat cardiac myocytes. Endocrinology 147, 1386-1395. doi: 10.1210/en.2005-1139

Virani, S. S., Alonso, A., Benjamin, E. J., Bittencourt, M. S., Callaway, C. W., Carson, A. P., et al. (2020). Heart disease and stroke statistics-2020 update: a report from the american heart association. Circulation 141, e139-e596. doi: 10.1161/CIR.0000000000000757

Wang, F., He, Q., Sun, Y., Dai, X., and Yang, X.-P. (2010). Female adult mouse cardiomyocytes are protected against oxidative stress. Hypertension 55, 11721178. doi: 10.1161/HYPERTENSIONAHA.110.150839

Wang, F., Yang, J., Sun, J., Dong, Y., Zhao, H., Shi, H., et al. (2015). Testosterone replacement attenuates mitochondrial damage in a rat model of myocardial infarction. J. Endocrinol. 225, 101-111. doi: 10.1530/JOE-140638

Wang, H., Sun, X., Lin, M. S., Ferrario, C. M., Van Remmen, H., and Groban, L. (2018). G protein-coupled estrogen receptor (GPER) deficiency induces cardiac remodeling through oxidative stress. Transl. Res. 199, 39-51. doi: 10.1016/j.trsl. 2018.04.005

Wang, Q., Li, L., Li, C. Y., Pei, Z., Zhou, M., and Li, N. (2015). SIRT3 protects cells from hypoxia via PGC-1alpha- and MnSOD-dependent pathways. Neuroscience 286, 109-121. doi: 10.1016/j.neuroscience.2014. 11.045

Wang, Q., and Zou, M. H. (2018). Measurement of reactive oxygen species (ROS) and mitochondrial ROS in AMPK knockout mice blood vessels. Methods Mol. Biol. 1732, 507-517. doi: 10.1007/978-1-4939-7598-3_32

Witayavanitkul, N., Woranush, W., Bupha-Intr, T., and Wattanapermpool, J. (2013). Testosterone regulates cardiac contractile activation by modulating SERCA but not NCX activity. Am. J. Physiol. Heart Circ. Physiol. 304, H465H472. doi: 10.1152/ajpheart.00555.2012

Witt, H., Schubert, C., Jaekel, J., Fliegner, D., Penkalla, A., Tiemann, K., et al. (2008). Sex-specific pathways in early cardiac response to pressure overload in mice. J. Mol. Med. 86, 1013-1024. doi: 10.1007/s00109-0080385-4

Xiao, F. Y., Nheu, L., Komesaroff, P., and Ling, S. (2015). Testosterone protects cardiac myocytes from superoxide injury via NF-kappaB signalling pathways. Life Sci. 133, 45-52. doi: 10.1016/j.lfs.2015.05.009

Yang, S.-H., Liu, R., Perez, E. J., Wen, Y., Stevens, S. M., Valencia, T., et al. (2004). Mitochondrial localization of estrogen receptor $\beta$. Proc. Natl. Acad. Sci. U.S.A. 101, 4130-4135. doi: 10.1073/pnas.0306948101

Yasar, P., Ayaz, G., User, S. D., Gupur, G., and Muyan, M. (2017). Molecular mechanism of estrogen-estrogen receptor signaling. Reprod. Med. Biol. 16, 4-20. doi: $10.1002 / \mathrm{rmb} 2.12006$ 
Zhang, L., Wu, S., Ruan, Y., Hong, L., Xing, X., and Lai, W. (2011). Testosterone suppresses oxidative stress via androgen receptor-independent pathway in murine cardiomyocytes. Mol. Med. Rep. 4, 1183-1188. doi: 10.3892/mmr. 2011.539

Zhao, D., Guallar, E., Ouyang, P., Subramanya, V., Vaidya, D., Ndumele, C. E., et al. (2018). Endogenous sex hormones and incident cardiovascular disease in postmenopausal women. J. Am. Coll. Cardiol. 71, 2555-2566. doi: 10.1016/j.jacc. 2018.01.083

Zhaolin, Z., Guohua, L., Shiyuan, W., and Zuo, W. (2019). Role of pyroptosis in cardiovascular disease. Cell Prolif. 52:e12563. doi: 10.1111/cpr. 12563

Ziaei, S., and Mohseni, H. (2013). Correlation between hormonal statuses and metabolic syndrome in postmenopausal women. J. Fam. Reprod. Health 7, 63-66.
Zimmerman, M. A., Budish, R. A., Kashyap, S., and Lindsey, S. H. (2016). GPERnovel membrane oestrogen receptor. Clin. Sci. 130, 1005-1016. doi: 10.1042/ CS20160114

Conflict of Interest: The authors declare that the research was conducted in the absence of any commercial or financial relationships that could be construed as a potential conflict of interest.

Copyright (C) 2021 Lynch, Boyett, Smith and Giordano-Mooga. This is an open-access article distributed under the terms of the Creative Commons Attribution License (CC BY). The use, distribution or reproduction in other forums is permitted, provided the original author(s) and the copyright owner(s) are credited and that the original publication in this journal is cited, in accordance with accepted academic practice. No use, distribution or reproduction is permitted which does not comply with these terms. 